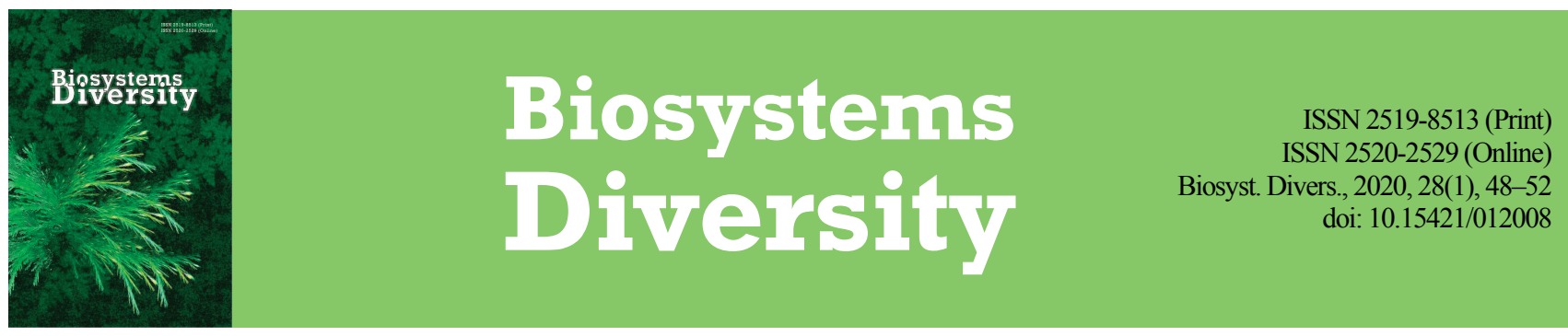

\title{
Adaptive strategy of Rapana venosa (Gastropoda, Muricidae) in the invasive population of the Black Sea
}

\author{
E. E. Slynko****, Y. V. Slynko**, V. I. Rabushko** \\ *Papanin Institute for Biology of Inland Waters, Russian Academy of Sciences, Borok \\ **A. O. Kovalevsky Institute of Biology of the Southern Seas of RAS, Moscow
}

\section{Article info \\ Received 19.01.2020 \\ Received in revised form 07.02.2020 \\ Accepted 10.02.2020}

Papanin Institute for Biolog of Inland Waters, Russian Academy of Sciences, Borok, 152742, Russia. Tel.: +8-915-969-98-09. E-mail:

elena.slynko.76@mail.ru

A. O. Kovalevsky Institute of Biology of the Southern Seas of RAS, Leninsky Prospekt, 38, korp. 3, Moscow, 119991, Russia. Tel.: +8-915-976-15-85. E-mail:yslynko@mail.ru

\author{
Slynko, E. E., Slynko, Y. V., \& Rabushko, V. I. (2020). Adaptive strategy of Rapana venosa (Gastropoda, Muricidae) in the inva- \\ sive population of the Black Sea. Biosystems Diversity, 28(1), 48-52. doi:10.15421/012008
}

We conducted molecular-genetic and morphological studies on the veined rapa whelk Rapana venosa (Valenciennes, 1846) in the Crimean waters of the Black Sea in order to determine possible reasons of the invasive success of this mollusk. Molecular-genetic tests were performed using COI gene; the surveyed samples reliably identified to $R$. venosa species. We compared the data on initial (from the Far-Eastern seas) and some invasive populations. In the natural conditions of the Yellow, East China Seas, and the Sea of Japan, the genetic diversity of rapa whelk is high $(\mathrm{Hd}=0.933, \pi=0.002)$. In all the invasive populations of rapa whelk (Black Sea, European and North American), an extremely low level of haplotypic and nucleotide diversity was determined $(\mathrm{Hd}=0.0, \pi=0.0)$. Despite low values of genetic diversity, the invasive populations of rapa whelk are characterized by ecological success. We noted stable growth of populations, tolerance to diseases and parasites, effective reproduction, high fertility. This contradicts the main provisions of the population genetics theory of formation of edge of range populations, because usually only a small number of specimens of rapa whelk were introduced. The explanations of the unique condition of the invasive populations of rapa whelk, both from an ecological perspective (high resistance to fluctuations of hydrological factors and chemical pollution, absence of enemies, high fertility) and genetic perspective (high selective value of separate haplotypes settled in the new water areas) have not been confirmed. We determined that a very important factor for the naturalization of the rapa whelk at low genetic diversity is the intra-species morpho-ecological divergence. In the Crimean water area of the Black Sea, $R$. venosa was found to have two morpho-ecological forms associated with the peculiarities of the development of the proportions of the shell. Study of successful invasive species would allow timely and adequate reaction to new cases of introduction.

Keywords: rapa whelk; COI gene; invasions; morpho-ecological forms; distribution.

\section{Introduction}

Rapa whelk Rapana venosa (Valenciennes, 1846) is one of the brightest examples of global expansion of hydrobionts. The current original name of the species has a great deal of synonyms: Purpura venosa (Valenciennes, 1846), R. thomasiana (Crosse, 1861), R. marginata (Valenciennes, 1846), R. pechiliensis (Grabau \& King, 1928) and $R$. pontica (Nordsieck, 1969). The natural range of the rapa whelk is the water areas of the Yellow, Bohai, East China Seas, and the Sea of Japan. Molecular surveys revealed high genetic diversity among the natural populations and the fact that this is not associated with geographic distance between populations (Chandler et al., 2008; Kim et al., 2012; Shen et al., 2016). Populations of the Far Eastern Seas have been affected by overexploitation and have rapidly decreased (Yang et al., 2008).

For the first time beyond its range, $R$. venosa was recorded in the water area of the Black Sea in 1947. According to some data, this species was brought in on the bottoms of Soviet torpedo boats transferred from the Sea of Japan (Pereladov, 2013). From the Black Sea, the rapa whelk penetrated the Azov Sea already by 1950s, and spread to the Sea of Marmara in 1960s, and further to the Mediterranean Sea, where it was found in the Adriatic Sea in 1973 (Savini et al., 2004) and the Aegean Sea in 1986 (Koutsoubas \& Voultsiadou-Koukoura, 1991). There are a few reports about discovery of $R$. venosa in the Tyrrhenian Sea (Savini \& Occhipinti-Ambrogi, 2006). In 1997, it was found in Brittany, on the Atlantic coast of France (Goulletquer et al., 2002), and in 1992 - in the North Sea south of the Dogger Bank (Mannet al., 2000). Rapa whelk was discovered in the south of the North Sea in 2005 (Kerckhof et al., 2006), and the Atlantic coast of Spain in 2007 (Rolán et al., 2007). Also, $R$. venosa was introduced to the Chesapeake Bay in the
East Coast of the USA, where it was for the first time discovered in 1998 (Mann \& Harding, 2000), and the same year - in the La Plata River between Uruguay and Argentina (Giberto et al., 2006; Lanfranconi et al., 2009, Carranza et al., 2010). It is assumed that the probable vector of its invasion of the coasts of America, in particular the Pacific waters of the North America was its introduction with cultivated true oysters, though this fact has not been confirmed reliably.

Molecular and genetic-biochemical surveys determined that in the areas of introduction of rapa whelk, unusual decrease in the level of genetic variability was observed by genes of mtDNA and microsatellites (Xue et al., 2018). Therefore, by genes of mtDNA, there was discovered one haplotype present in two native populations of the East China Sea and the Sea of Japan, indicating that precisely these regions are the source of introduction to the Black Sea (Chandler et al., 2008). $R$. venosa is a predatory gastropod which mainly feeds on Bivalvia. Small snails feed by drilling holes in the umbos of the shell, whereas large snails can attack and consume Bivalvia by smothering (Harding et al., 2007). In the Black Sea, during the first year, rapa whelk grows up to $20-40 \mathrm{~mm}$, the average size of the shell equals $65 \mathrm{~mm}$ for second year individuals and $92 \mathrm{~mm}$ for six year-old individuals. Life expectancy of $R$. venosa can reach 12-18 years (Savini et al., 2004). $R$. venosa has a broad ecological amplitude in terms of temperature, salinity, deficiency of oxygen and pollution, is tolerant to changes in salinity (7-32\%) and temperature (4 $27^{\circ} \mathrm{C}$ ) (Mann \& Harding, 2003), which probably allows these animals to tolerate prolonged transportation and inhabit new areas. In its newly colonized territories, $R$. venosa prefers rocky, stony, sandy or sandy-silty seabeds (Koutsoubas \& Voultsiadou-Koukoura, 1991; Seyhan et al., 2003; Bondarev, 2010). Due to the absence of natural enemies in the Black and Azov Seas, the population of these mollusks has quickly spread and 
caused significant damage to their fauna . Though there are no field observations of predators which consume rapa whelk in places of introduction, laboratory experiments demonstrated that some crabs can feed on small mollusks (Harding, 2003). In the natural range and newly colonised areas, $R$. venosa demonstrates stability of the main conchological characteristics, therefore it can be easily diagnosed (Pereladov, 2013), and the sexual dimorphism in the shell of rapa whelk is absent. In general, a paradoxical situation has developed: one of the most effective and successful invasive species throughout the wide and diverse area of its new range is characterized by extremely low genetic variability (low heterozygosity, extremely low haplotypic and nucleotide diversity, low inter-group subdivision). As a general rule, researchers try to explain the paradox by reproductive and ontogenetic peculiarities of rapa whelk: high fertility, presence of plankton larva (veliger), fast ontogenesis and maturation (Chandler et al., 2008).

Therefore the objective of the present work was the description of genetic diversity of $R$. venosa in the invasive population which lives on the shelf of the Crimean Peninsula of the Black Sea and the search for the reasons for the adaptive success of this mollusk.

\section{Materials and methods}

The mollusks were collected in 2018 in the Karantin Bay (Sevastopol) under the collectors of the mussel and oyster farm. A total of 10 mature specimens were selected for molecular-genetic analysis. As soon as the live mollusks were delivered to the laboratory, their bodies were extracted from the shell and a sample was taken from the leg and fixated in $96 \%$ ethanol. Total DNA was extracted from the tissue of the mollusk's leg using an innuPREP DNA Mini Kit set (Analytik Jena company, Germany). Analysis of nucleotide sequences was performed using mitochondrial gene COI. The COI fragment of the length of $608 \mathrm{bp}$ was amplified using previously developed primers (Slynko et al., 2018):

Forward - LCO1490: 5'-GGTCAACAAATCATAAAGATATTGG-3', Reverse-HCO2198: 5'-TAAACTTCAGGGTGACCAAAAAATCA-3'.

As the amplifying mixes, we used the preprepared lyophilized mixes (master mixes) for DNA amplification in the volume of $20 \mathrm{mcL}$ Master mixes for separate reaction contained all components necessary for the reaction, including Taq DNA polymerase inhibited for "hot start", dNTP and dye for electrophoresis (PLC Genlab Scientific-productive company, Moscow). Polymerase chain reaction was performed in the following sequence: $94{ }^{\circ} \mathrm{C}-2.5 \mathrm{~min}, 94{ }^{\circ} \mathrm{C}-30 \mathrm{~s} 35$ cycles, $58^{\circ} \mathrm{C}-1 \min 35$ cycles, $72^{\circ} \mathrm{C}-1 \min 35$ cycles, $72^{\circ} \mathrm{C}-10 \mathrm{~min}$. By COI gene of mtDNA, we obtained amplicons for the numbers from 1 to 10 inclusively. The obtained PCR-products were sequenced on the basis of Evrogen Ru (Moscow) LTD in forward and reverse directions. A phylogenetic tree with the calculation of bootstrap supports of the branching nodes (1,000 replications) was developed in MEGA 7.0 program using the method of "nearest neighbor" (Neighbor Joining, NJ) (Saitou \& Nei, 1987).

The parameters of genetic variability were calculated using the DNASP 5.10 software pack (Librado \& Rozas, 2009). For comparison, we used the data on haplotypes of COI of the corresponding length of $R$. venosa taken from GenBank, NCBI (NCBI) from the Chesapeake Bay (Chandler et al., 2008; Aguilar et al., 2018), aquatoria of the Black Sea near the coasts of Turkey and the East China Sea, Yellow Sea and the Sea of Okhotsk from the coasts of Korea and Japan (Chandler et al., 2008; Kim et al., 2012; Sun \& Yang, 2016). As the external group, we used another representative of the Muricidae family - Ergalatax margariticola (Broderip in Broderip \& Sowerby, 1833) (FR853861).

Individual ontogenetic channels were determined for 25 mature mollusks; for achieving this goal we assessed the morphological variability of the shell according to 6 characters: height $(H)$, width (D), height of the whorl (ls), length of the main body of the shell from the aperture to the apical whorl (lps), length of the aperture (lu), width of the aperture (hu). For the measurements, we used mature individuals with height of the shell equaling 65 to $95 \mathrm{~mm}$. Characters of streamlined shape of the exterior morphology are represented in the indices in \% of the shell's height. The data were statistically analyzed using multi-dimensional methods of analysis with Statistica 6.0 software pack. In the analysis of the principal components the vectors were calculated using covariances matrix. The length of vector was assumed to equal 1 . The contours of the scatter formed by the individuals on PC1 and PC2 plane were considered to be the boundaries of ontogenetic channel, i.e. the projection of the area of the multidimensional space of characters in which the individual ontogenetic trajectories were located (Mina, 2001).

\section{Results}

Molecular-genetic analysis. In all 10 individuals of $R$. venosa from the Crimean water area, according to the fragment of 608 bp length, one COI haplotype corresponded to identical fragments from the Yellow, East China Seas and the Sea of Japan (KP136708, KP136707, KP136661, KP136659), massively present in the population of the Turkish water area of the Black Sea (KP136660, KP136661) and Chesapeake Bay of the USA (MH087553, EU250090, EU250111) (Fig. 1, Table 1).

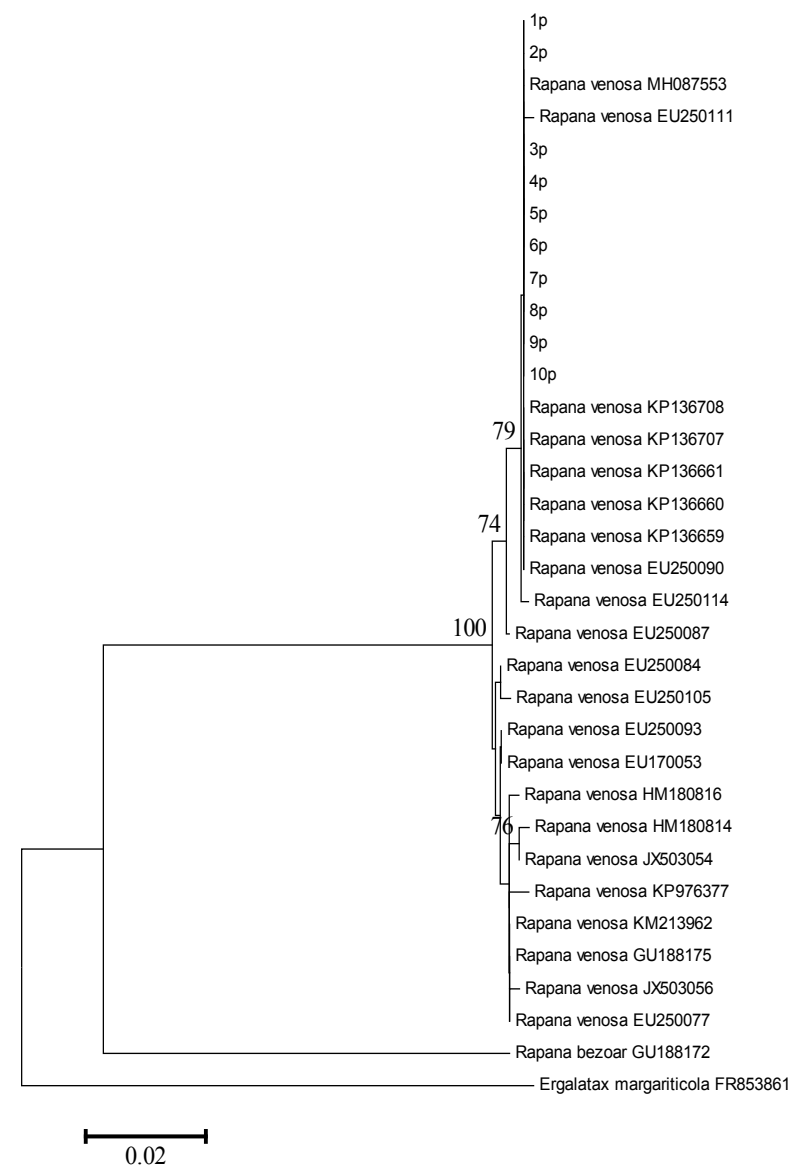

Fig. 1. Neighbor Joining tree of phylogenetic relations of haplotypes of COI of Rapana venosa of the Crimean water area of the Black Sea (1p-10p), other invasive and initial populations of rapa whelk: haplotypes with letters KP - Turkish water area of the Black Sea, EU - Chesapeake Bay of the USA (except EU250077), the rest haplotypes, including EU250077, - Yellow, East China Seas, and the Sea of Japan; as external groups, $R$. besoar and Ergalatax margariticola are indicated; bootstrap supports are indicated in their branching nodes; below the figure the unit of measurement of the lengths of the branches is given -0.02 nucleotides

It is important that in rapa whelks from different populations the substitution of nucleotides occurred singularly. At the same time, the substitutions of the transition type definitely dominated. Transversions were usually much rarer (Table 2). The data obtained on the point mutation were confirmed by the analysis of the parameters of the genetic variability. Therefore, the highest values of the haplotype and nucleotide diversity, intra-group differentiation, amount of haplotypes, percentage of mutations were seen in the natural part of the range and the minimum values of these parameters - in the invasive populations (Table 3 ), the lowest values being observed in the Black Sea, and moreover particularly in the Crimean water area. 
Table 1

Matrix of distances (p) between the sequences of 607 pairs of nucleotides of COI genes of Rapana genus

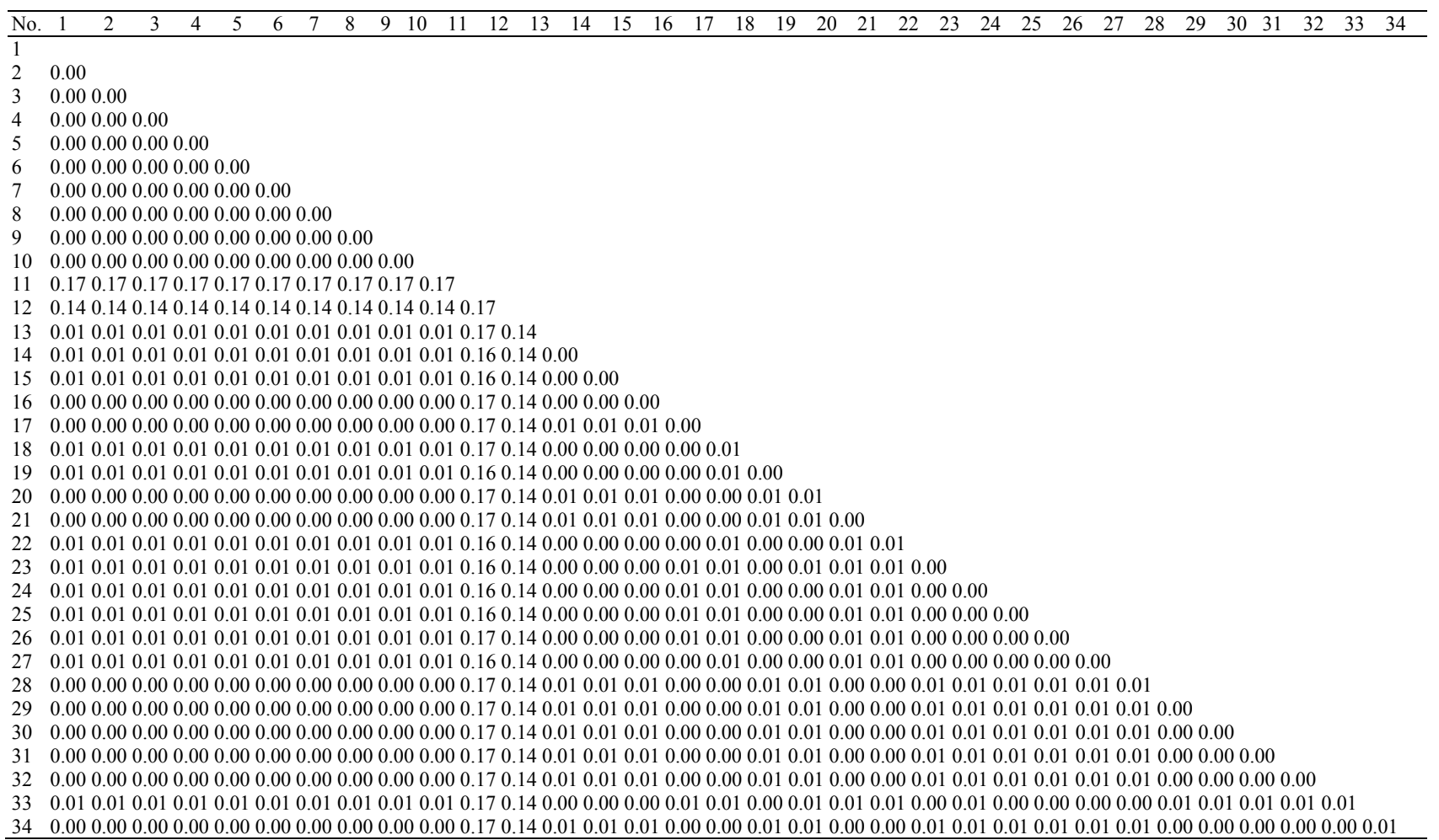

Note: matrix of distances calculated according to Tamura et al. (2011): notation keys: 1 - 10p, 2-10 - 1p-9p, 11 - Ergalatax margariticola: FR853861(external group), 3, 12 - R. bezoar: GU188172, 13 - R. venosa: EU170053, 14 - EU250077, 15 - EU250084, 16 - EU250087, 17 - EU250090, 18 - EU250093, 19 EU250105, 20 - EU250111, 21 - EU250114, 22 - GU188175, 23 - HM180814, 24 - HM180816, 25 - JX503054, 26 - JX503056, 27 - KM213962, 28 KP136659, 29 - KP136660, 30 - KP136661, 31 - KP136707, 32 - KP136708, 33 - KP976377, 34 - MH087553; cadastral numbers from the NCBI are indicated.

\section{Table 2}

Estimation of maximum likelihood of the pattern of nucleotide substitution by the sum of 607 pairs of nucleotides in rapa whelk Rapana venosa of the water area of the Black Sea

\begin{tabular}{ccccc}
\hline Nucleotides & $\mathrm{A}$ & $\mathrm{T}$ & $\mathrm{C}$ & $\mathrm{G}$ \\
\hline $\mathrm{A}$ & - & 2.53 & 1.07 & $11.83^{*}$ \\
$\mathrm{~T}$ & 1.66 & - & $17.87^{*}$ & 1.33 \\
$\mathrm{C}$ & 1.66 & $42.34^{*}$ & - & 1.33 \\
$\mathrm{G}$ & $14.77^{*}$ & 2.53 & 1.07 & - \\
\hline
\end{tabular}

Note: rates of substitutions by type of the transitions are indicated*; the frequencies of the nucleotypes equal $25.19 \%$ (A), 38.41\% (T), 20.18\% (C) and $16.21 \%(\mathrm{G})$; coefficients of the rate of the transitions/transversions equal $\mathrm{k}_{1}=8.886$ (purines) and $\mathrm{k}_{2}=16.707$ (pyrimidines); the total shift of the transitions/transversions equal $\mathrm{R}=6.021$, where $\mathrm{R}=\left[\mathrm{A} * \mathrm{G} * \mathrm{k}_{1}+\mathrm{T} * \mathrm{C} *\right.$ $\left.\mathrm{k}_{2}\right] /[(\mathrm{A}+\mathrm{G}) *(\mathrm{~T}+\mathrm{C})]$.

Table 3

Parameters of genetic variability of the COI gene in some invasive and initial populations of rapa whelk Rapana venosa

\begin{tabular}{|c|c|c|c|c|c|c|}
\hline Populations & $\mathrm{n}$ & $\mathrm{S}$ & $\mathrm{H}$ & $\mathrm{Hd}$ & $\pi$ & $\mathrm{K}$ \\
\hline $\begin{array}{l}R \text {. venos } a \text { of the Crimean water } \\
\text { area of the Black Sea }\end{array}$ & 10 & 0.0 & 1 & 0 & 0 & 0 \\
\hline $\begin{array}{l}R \text {. venosa of the Turkish water } \\
\text { area of the Black Sea }\end{array}$ & 10 & 0.0 & 1 & 0 & 0 & 0 \\
\hline $\begin{array}{l}\text { R. venosa of the Chesapeake } \\
\text { Bay of the USA }\end{array}$ & 10 & 0.0 & 1 & 0 & 0 & 0 \\
\hline R. venosa of the Far-East Seas & 30 & 40.0 & 23 & 0.933 & 0.002 & 6.206 \\
\hline
\end{tabular}

Note: $\mathrm{n}$ - number of the studied specimens, $\mathrm{S}$ - number of polymorphic sites, $\mathrm{h}$ - number of haplotypes, $\mathrm{Hd}$ - haplotypic diversity, $\pi$ - nucleotide diversity, $\mathrm{K}$ - intra-group nucleotide differentiation.

The analysis of morphological characters of the shell revealed that in the space of the principal components the differentiation of individuals is absent (Fig. 2). This is quite obvious, for the mature individuals of approximately close sizes ( 65 to $95 \mathrm{~mm}$ high) were selected. However, during the approximation of the values of the first and second components (Table 4) for the height of the shell, we observed the formation of the two trajectories of the development (Fig. 3, 4). The scatters of distribution were seen especially distinctly in the projection of the second component onto the height of the shell (Fig. 4).

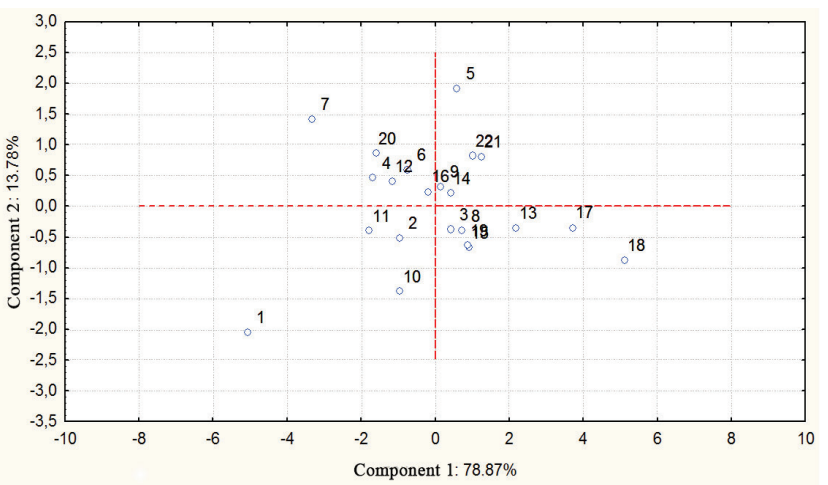

Fig. 2. Distribution of Rapana venosa individuals in the space of the principal components in total of 7 morphometric characters of the shell

\section{Discussion}

Study of nucleotide structure of the COI gene confirmed the conclusion drawn by previous researchers on the mono-morphisation in the populations of the rapa whelk throughout their recently colonised range (Chandler et al., 2008; Shen et al., 2016; Aguilar et al., 2018). Furthermore, if we take into account that the expansion of rapa whelk began from the Black Sea, then the haplotypic uniformity of COI in the Crimean water body clearly demonstrates that for more than 70 years of living in the basin, no accumulation of diversity is observed. The data we obtained on the proportion of transitions and transversions indicate 
the stability of the COI gene in rapa whelk and also extremely low mutational potential of this gene in this species. This is especially clearly confirmed by comparison of the rapa whelk from the Turkish and Romanian water areas of the Black Sea.

\section{Table 4}

Eigenvector loadings on the first and the second principal components by the morphological features of the rapa whelk from the population of the Crimean water area of the Black Sea

\begin{tabular}{crc}
\hline Morphological characters & Component 1 & Component 2 \\
\hline 1 & -5.487 & -2.091 \\
2 & -1.216 & -0.518 \\
3 & 0.220 & -0.399 \\
4 & -1.957 & 0.496 \\
5 & 0.429 & 2.008 \\
6 & -0.976 & 0.633 \\
7 & -3.656 & 1.483 \\
8 & 0.547 & -0.403 \\
9 & -0.057 & 0.344 \\
10 & -1.199 & -1.429 \\
11 & -2.063 & -0.406 \\
12 & -1.407 & 0.428 \\
13 & 2.056 & -0.364 \\
14 & 0.199 & 0.239 \\
15 & 0.709 & -0.685 \\
16 & -0.391 & 0.263 \\
17 & 3.643 & -0.357 \\
18 & 5.087 & -0.917 \\
19 & 0.684 & -0.655 \\
20 & -1.871 & 0.906 \\
21 & 1.105 & 0.840 \\
22 & 0.830 & 0.861 \\
\hline
\end{tabular}

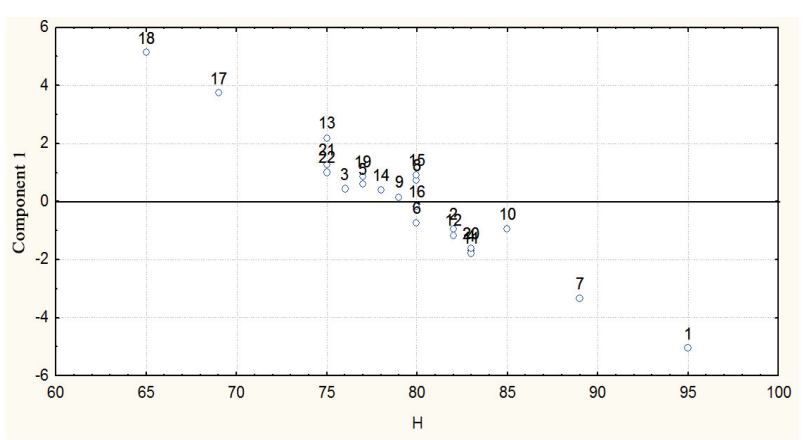

Fig. 3. Two-dimensional distribution of Rapana venosa individuals from the populations of the Crimean water area of the Black Sea, component 1: on the abscissa axis - height of the shell $(\mathrm{H}, \mathrm{mm})$; on the ordinate axis - values of the first principal component $(a)$ and the second component $(b)$ by the morphological characters of

the body; lines in the middle - solld - the boundaries of the ontogenetic channels, dotted line - their confidence intervals

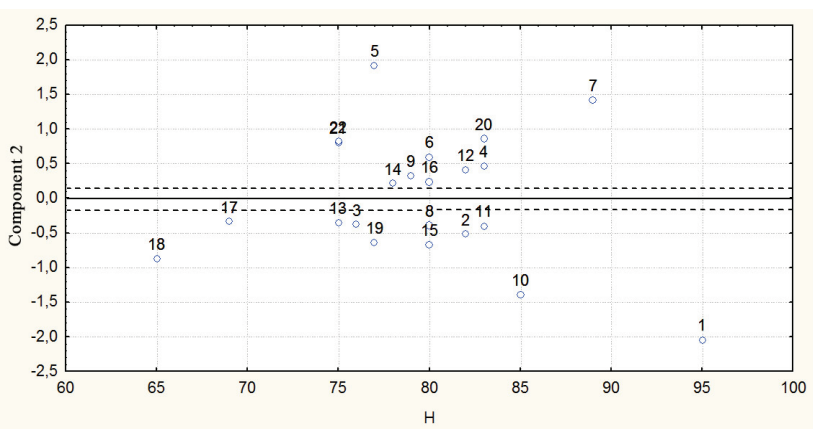

Fig. 4. Two-dimensional distribution of Rapana venosa individuals from the populations of the Crimean water areas of the Black Sea, component 2: on the abscissa axis - height of the shell $(\mathrm{H}, \mathrm{mm})$; on the ordinate axis - values of the first principal component $(a)$ and the second component $(b)$ by morphological characters of the body; lines in the middle - solld - boundaries of ontogenetic channels, dotted line - their confidence intervals
At the same time, we should note that the population of rapa whelk of the Black Sea has entered the period of its stabilization characterized by periodic standardized fluctuations of the number (Odum, 1985). At the same time, despite the intense fishing, the population of the Black Sea is quite stable, the density has for many years remained within the range of 0.01-0.05 spec. $/ \mathrm{m}^{2}$ (Revkov, 2009; Bondarev, 2010; Pereladov, 2013).

Many attempts have been made to explain such unique condition of the invasive populations of rapa whelk, both from an ecological perspective (active predation, absence of enemies, good food base, high fertility and fast maturation, plankton stage - veliger, high tolerance to the fluctuations of hydrological-hydrochemical factors and chemical pollutions) (Mann \& Harding, 2003; Bondarev, 2010; Pereladov, 2013), and from the genetic perspective (high selective value of separate haplotypes settled in the new water areas) (Chandler et al., 2008; Kim et al., 2012; Zou et al., 2012). The explanation of the latter phenomenon is given from the positions of the principle of the founder and the bottleneck effect (Westphal et al., 2008; Wilson et al., 2009). Actually the only success of the application of this principle regarding the rapa whelk was the confirmation of the fact that most likely introductions and multiple invasions of this mollusk from various places to the Black Sea did not occur (Roman \& Darling, 2007). However, such significant genetic monomorphisation of rapa whelk in the Black Sea was not anyhow explained. It was only noted that long term stability of this population is impossible (Sakai et al., 2001), whereas the analysis of ecological and morphological peculiarities of rapa whelk in newly colonized areas, first of all the Black Sea, allowed some authors to state that this population is ecologically flexible and will evolutionally prosper in future (Bondarev, 2010; Pereladov, 2013). The most significant argument for this statement was the analysis of the tendencies of change in growth and peculiarities of the habitus of the shell in the individuals of rapa whelk, representing both different populations and at the intra-populational level. It revealed the existence of several eco-morphological forms (i.e. "typical" and "dwarf", the latter includes the "Thais" (Stramonita) form) in different regions of the Black Sea (Cesari et al., 1985; Giberto et al., 2006; Bondarev, 2010). The existence of different forms is supported by the data on the peculiarities of diet, and biotope of the rapa whelk. The drilling type of feeding is more characteristic for small forms. At the same, for the natural part of the range the presence of ecomorphs of rapa whelk is not that notable, which is also true for their size-age structure (Razin, 1934).

The determination of two trajectories of development (chreods of ontogenesis) completely confirms the fairness of the presumption of existence of morpho-ecological forms of rapa whelk in the Black Sea. Clearly seen is the formation of scatters particularly by the second component, indicating the difference in the programmes of the development directly related to the formation of the proportions of the shell rather than its linear growth (Tissot, 1988). This is confirmed, on the one hand, by the existence of morpho-ecological forms of rapa whelk, and on the other hand connects their formation with the linear growth as presumed by the previous authors (Giberto et al., 2006; Bondarev, 2010). The observed phenotypic divergence implicating the intra-species diversification (Ward \& McLennan, 2009; Berner et al., 2010) confirms one of the basic theses of the contemporary theory of bioinvasions that most notably the mechanisms of bioinvasions manifest during the trans-continental transfers (Elton, 1960) and are expressed first of all in the implementation of the adaptive compromise of the epigenetic theory of evolution (Shmalgauzen, 1982).

\section{Conclusions}

Thus, $R$. venosa, 70 years after its introduction to the Black Sea maintains its high abundance, ecological flexibility and significant tolerance to the environmental factors. By COI gene, it was confirmed that in the invasive populations of rapa whelk in different areas of the Global Ocean, its genetic variation is at extremely low level. At the same time, it is assumed that in the populations of the Crimean water area of the Black Sea, there are observed at least two ontogenetic programmes of the development which affect the morphometric proportions of the shell and perhaps manifest in the intra-species diversification of the rapa 
whelk - formation of two morpho-ecological forms. Therefore, the phenomenon of significant ecological success of the rapa whelk in the invasive populations around the world at extremely low genetic variation is caused first of all by achieving adaptive compromise and formation of several trends of the development.

The authors express gratitude to the worker of the Institute of Biology of the Southern Seas S. V. Shchurov for catching rapa whelk. The study was performed within the framework of the State topics No AAAA-A18118020790229-7, No AAAA-A18-118021350003-6 and No AAAA-A18118012690105-0, and the grant of RFBR No 18-44-920004.

\section{References}

Aguilar, R., Ogburn, M. B., Driskell, A. C., Weigt, L. A., Groves, M. C., \& Hines, A. H. (2016). Gutsy genetics: Identification of digested piscine prey items in the stomach contents of sympatric native and introduced warmwater catfishes via DNA barcoding. Environmental Biology of Fishes, 100, 325-336.

Berner, D., Stutz, W. E., \& Bolnick, D. I. (2010). Foraging trait (co)variances in stickleback evolve deterministically and do not predict trajectories of adaptive diversification. Evolution, 64, 2265-2277.

Bondarev, I. P. (2016). Struktura populyacij Rapana venosa (Gastropoda, Muricidae) sevastopol'skih buht (Chyornoe more) [Population structure of Rapana venosa (Gastropoda, Muricidae) of Sevastopol bays (Black Sea)]. Morskoj Biologicheskij Zhurnal, 1(3), 14-21 (in Russian)

Carranza, A., de Mello, C., Ligrone, A., Gonzalez, S., Piriz, P., \& Scarabino, F. (2010). Observations on the invading gastropod Rapana venosa in Punta del Este, Maldonado Bay, Uruguay. Biological Invasions, 9534, 27-31.

Chandler, E. A., McDowell, J. R., \& Graves, J. E. (2008). Genetically monomorphic invasive populations of the rapa whelk, Rapana venosa. Molecular Ecology, 17, 4079-4091.

Dae-Won, K., Yoo, W. G., Park, H. C., Yoo, H. S., Kang, D. W., Jin, S. D., Min, H. K., Paek, W. K., \& Lim, J. (2012). DNA barcoding of fish, insects, and shellfish in Korea. Genomics and Informatics, 10(3), 206-211.

Elton, C. (1960). Ekologiya nashestvij zhivotnyh i rastenij [Ecology of invasions of animals and plants]. Inostrannaya Literatura, Moscow (in Russian).

Giberto, D. A., Bremec, C. S., Schejter, L., Schiariti, A., Mianzan, H., \& Acha, E. M. (2006). The invasive rapa whelk Rapana venosa (Valenciennes, 1846): Status and potential ecological impacts in the Río de la Plata estuary, ArgentinaUruguay. Journal of Shellfish Research, 25(3), 919-924.

Goulletquer, P., Bachelet, G., Sauriau, P. G., \& Noel, P. (2002). Open Atlantic coast of Europe - a century of introduced species into French waters. In: Invasive aquatic species of Europe. Distribution, impacts and management. Kluwer Academic Publishers, Dordrecht.

Harding, J. M., Kingsley-Smith, P., Savini, D., \& Mann, R. (2007). Comparison of predation signatures by Atlantic oyster drills (Urosalpinx cinerea Say, Muricidae) and veined rapa whelks (Rapana venosa Valenciennes, Muricidae) in bivalve prey. Journal of Experimental Marine Biology and Ecology, 352, 1-11.

Kerckhof, F., Vink, R. J., Nieweg, D. C., \& Post, J. N. J. (2006). The veined whelk Rapana venosa has reached the North Sea. Aquatic Invasions, 1(1), 35-37.

Koutsoubas, D., \& Voultsiadou-Koukoura, E. (1991). The occurrence of Rapana venosa (Valenciennes, 1846) (Gastropoda, Thaididae) in the Aegean Sea. Bolletino Malacogico, 26(10-12), 201-204.

Lanfranconi, A., Hutton, M., Brugnoli, E., \& Muniz, P. (2009). New record of the alien mollusc Rapana venosa (Valenciennes 1846) in the Uruguayan coastal zone of Rio de la Plata. Pan-American Journal of Aquatic Sciences, 4(2), 216-221.

Librado, P., \& Rozas, J. (2009). DnaSP v5: A software for comprehensive analysis of DNA polymorphism data. Bioinformatics, 25(11), 1451-1452.

Mann, R., \& Harding, J. M. (2000). Invasion of the North American Atlantic coast by a large predatory Asian mollusk. Biological Invasions, 2, 7-22.

Mann, R., \& Harding, J. M. (2003). Salinity tolerance of larval Rapana venosa: Implications for dispersal and establishment of an invading predatory gastropod on the North American Atlantic coast. Biological Bulletin, 204, 96-103.
Mina, M. V. (2001). Morphological diversification of fish as a consequence of the divergence of ontogenetic trajectories. Russian Journal of Developmental Biology, 32, 397-402.

Odum, E. P. (1985). Trends expected in stressed ecosystems. Bio-Science, 35, 419-422.

Pereladov, M. V. (2013). Sovremennoe sostoyanie populyacii i osobennosti biologii rapany (Rapana venosa) v severo-vostochnoj chasti Chyornogo moray [The current state of the population and the biology of the Rapana venosa in the northeastern Black Sea]. Trudy VNIRO, 150, 8-20 (in Russian).

Revkov, N. K. (2009). Nekotorye zamechaniya po sostavu i mnogoletnej dinamike fauny mollyuskov ryhlyh gruntov yugo-vostochnogo Kryma (Chernoe more) [Some comments on the composition and long-term dynamics of the mollusk fauna of loose soils if the south-eastern Crimea (Black Sea)]. Karadag-2009. Ekosi-Gidrofizika, Sevastopol. Pp. 251-261 (in Ukrainian). https://doi.org/10.13140/RG.2.1.1962.2881

Roman, J., \& Darling, J. A. (2007). Paradox lost: Genetic diversity and the success of aquatic invasions. Trends in Ecology and Evolution, 22, 454 464.

Saitou, N., \& Nei, M. (1987). The neighbor-joining method: A new method for reconstructing phylogenetic trees. Molecular Biology and Evolution, 4(4), 406-425.

Sakai, A. K., Allendorf, F. W., Holt, J. S., Lodge, D. M., Molofsky, J., With, K. A., Baughman, S., Cabin, R. J., Cohen, J. E., Ellstrand, N. C., McCauley, D. E., O’Neil, P., Parker, I. M., Thompson, J. N., \& Weller, S. G. (2001). The population biology of invasive species. Annual Review of Ecology and Systematics, 32, 305-332.

Savini, D., \& Occhipinti-Ambrogi, A. (2006). Consumption rates and prey preference of the invasive gastropod Rapana venosa in the Northern Adriatic Sea. Helgoland Marine Research, 60, 153-159.

Savini, D., Castellazzi, M., Favruzza, M., \& Occhipinti-Ambrogi, A. (2004). The alien mollusc Rapana venosa (Valenciennes, 1846; Gastropoda, Muricidae) in the Northern Adriatic Sea: Population structure and shell morphology. Chemistry and Ecology, 20(Suppl. 1), 411-424.

Seyhan, K., Mazlum, E. R., Emiral, H., Engin, S., \& Demirhan, S. (2003). Diel feeding periodicity, gastric emptying, and estimated daily food consumption of whelk (Rapana venosa) in the south eastern Black Sea (Turkey) marine ecosystem. Indian Journal of Marine Science, 32(3), 249-251.

Shen, Y., Kang, J., \& He, S. (2016). DNA barcoding for the identification of common economic aquatic products in Central China and its application for the supervision of the marked trade. Food Control, 61, 79-91.

Shmalgauzen, I. I. (1982). Organizm kak celoe v individual'nom $\mathrm{i}$ istoricheskom razvitii [The organism as a whole in individual and historical development]. Nauka, Moscow (in Russian).

Slynko, Y. V., Slynko, E. E., Pirkova, A. V., \& Ryabushko, V. I. (2018). Mitochondrial DNA barcoding of the pacific oyster Crassostrea gigas (Thunberg, 1793) (Mollusca: Bivalvia: Ostreidae), cultivated in the Black Sea. Russian Journal of Genetics, 54, 1445-1451.

Sun, X., \& Yang, A. (2016). The complete mitochondrial genome of Rapana venosa (Gastropoda, Muricidae). Mitochondrial DNA Part A: DNA Mapping, Sequencing, and Analysis, 27(2), 1471-1472.

Ward, J. L., \& McLennan, D. A. (2009). Historical and ecological correlates of body shape in the brook stickleback, Culaea inconstans. Biological Journal of the Linnean Society, 96(4), 769-783.

Westphal, M. I., Browne, M., MacKinnon, K., \& Noble, I. (2008). The link between international trade and the global distribution of invasive alien species. Biological Invasions, 10, 391-398.

Wilson, J. R. U., Dormontt, E. E., Prentis, P. J., Lowe, A. J., \& Richardson, D. M. (2009). Something in the way you move: Dispersal pathways affect invasion success. Trends in Ecology and Evolution, 24(3), 136-144.

Xue, D.-X., Graves, J., Carranza, A., Sylantyev, S., Snigirov, S., Zhang, T., \& Liu, J.-X. (2018). Successful worldwide invasion of the veined rapa whelk, $R a-$ pana venosa, despite a dramatic genetic bottleneck. Biological Invasions, 20(11), 3297-3314.

Yang, J., Li, Q., Kong, L., Zheng, X., \& Wang, R. (2008). Genetic structure of the veined rapa whelk (Rapana venosa) populations along the coast of China. Biochemical Genetics, 46, 539-548.

Zou, S., Li, Q., \& Kong, L. (2012). Multigene barcoding and phylogeny of geographically widespread muricids (Gastropoda: Neogastropoda) along the coast of China. Marine Biotechnology, 14(1), 21-34. 